\title{
Pengaruh Pendapatan Asli Daerah (PAD) dan Karakteristik Pemerintah Daerah terhadap Kinerja Keuangan Pemerintah Daerah Kabupaten/Kota Propinsi Papua
}

\author{
Mercy Irene Christine Siregar
}

\author{
Universitas Wijaya Kusuma- Fakultas Ekonomi Dan Bisnis
} siregarmercy50@gmail.com

\begin{tabular}{|c|}
\hline \multirow{2}{*}{$\begin{array}{l}\text { ARTICLEDETAILS } \\
\text { History }\end{array}$} \\
\hline \\
\hline Received \\
\hline RevisedFormat : September \\
\hline Accepted $\quad$ : Oktober \\
\hline
\end{tabular}

Keywords :

Corruption, government performance

\begin{abstract}
S
This study aims to identify and analyze the definition of corruption, to identify and analyze the causes of corruption, to the impact of corruption, to prevent and eradicate corruption. The benefits of research are the theoretical use of developing and expressing objectively in overcoming existing problems, especially those related to aspects of corruption and providing insight into information for the public, law enforcement agencies and other parties on the performance of the local government of the regency city of Jayapura.
\end{abstract}

(C)2020 STIM Lasharan Jaya Makassar

\section{PENDAHULUAN}

\section{Latar Belakang Masalah}

Sesuai Sesuai dengan undang - undang RI tahun 1945 pemerintah daerah berwenang untuk mengatur dan mengurus sendiri urusan pemerintahan menurut asas otonomi dan tugas pembantuan. Pemberian Otonomi yang luas kepada daerah diarahkan untuk mempercepat terwujudnya kesejahteraan masyarakat melalui peningkatan pelayanan, pemberdayaan, dan peran serta masyarakat. Disamping itu melalui otonomi yang luas daerah diharapkan mampu meningkatkan daya saing dengan memperhatikan prinsip demokrasi, pemerataan, keadilan, keistimewaan dan kekhususan serta potensi dan keanekaragaman daerah dalam sistim negara kesatuan RI.

Menurut UU No. 22 Tahun 1999 tentang Pemerintah Daerah, menyebutkan bahwa melalui otonomi daerah, pembangunan ekonomi daerah diharapkan terwujud melalui pengelolaan sumber-sumber daerah. Otonomi daerah merupakan kewenangan daerah otonom untuk mengatur dan mengurus kepentingan masyarakat setempat menurut prakarsa sendiri berdasarkan aspirasi masyarakat sesuai aturan perundang-undangan. Akan tetapi otonomi daerah yang saat ini sudah berjalan di pemerintah daerah kabupaten /kota Propinsi Papua masih menimbulkan persoalan baru karena pemanfaatan dan pengelolaan potensi fiskal pemerintah daerah kabupaten / kota Propinsi Papua masih menunjukan hasil yang kurang. Sehingga pertumbuhan ekonomi belum tercapai. Peneliti mencoba meneliti seberapa besar pengaruh Pendapatan Asli Daerah (PAD) dan Karakteristik berpengaruh terhadap kinerja keuangan pemerintah kabupaten / Kota di Propinsi Papua, serta komponen-komponen apa saja yang secara dominan mempengaruhi kinerja keuangan pemerintah kabupaten / Kota di Propinsi Papua periode 2009-2013.

Pemerintah diminta melaporkan hasil dari program yang telah dilaksanakan agar masyarakat dapat menilai. Wood (1998) mengungkapkan bahwa fungsi dari pengukuran kinerja dapat menjelaskan mengenai (1) Evaluasi bagaimana program tersebut berjalan; (2) Sarana perbandingan atas pelayanan yang diberikan; (3) Alat komunikasi dengan publik. Berdasarkan uraian di atas dapat disimpulkan bahwa pengukuran kinerja keuangan daerah adalah sesuatu 
yang penting untuk dilakukan. Pernyataan ini selaras dengan Greiling (2005) yang mengungkapkan bahwa salah satu kunci sukses dari pembaharuan dalam sektor publik adalah dengan melakukan pengukuran kinerja.

\section{Tujuan Penelitian}

Tujuan yang ingin dicapai dalam penelitian ini,adalah sebagai berikut :

1. Untuk mengetahui dan menganalisa pengaruh pendapatan asli daerah (PAD) terhadap kinerja keuangan Pemerintah Daerah kabupaten / kota Propinsi Papua

2. Untuk mengetahui dan menganalisa pengaruh ukuran pemerintah daerah terhadap kinerja keuangan kabupaten / kota Propinsi Papua

3. Untuk mengetahui dan menganalisa pengaruh leverage pemerintah daerah terhadap kinerja keuangan Pemerintah daerah Kabupaten / Kota Propinsi Papua

4. Untuk mengetahui dan menganalisa pengaruh dana perimbangan pemerintah daerah terhadap kinerja keuangan pemerintah daerah kabupaten / kota Propinsi Papua

\section{TINJAUAN PUSTAKA}

\section{Anggaran Pendapatan dan Belanja Daerah (APBD)}

UU No.32 tahun 2004 tentang Pemerintahan daerah menyebutkan bahwa Anggaran Pendapatan dan Belanja Daerah (APBD) adalah rencana keuangan tahunan pemerintahan daerah yang ditetapkan dengan peraturan daerah. APBD/N merupakan salah satu mesin pendorong pertumbuhan ekonomi.

Peranan APBD sebagai pendorong dan salah satu penentu tercapainya target dan sasaran makro ekonomi daerah diarahkan untuk mengatasi berbagai kendala dan permasalahan pokok yang merupakan tantangan dalam mewujudkan agenda masyarakat yang sejahtera dan mandiri.

Kebijakan pengelolaan APBD difokuskan pada optimalisasi fungsi dan manfaat pendapatan, belanja, dan pembiayaan bagi tercapainya sasaran atas agenda-agenda pembangunan tahunan. Di bidang pengelolaan pendapatan daerah akan terus diarahkan pada peningkatan PAD. Untuk merealisasikan hal tersebut akan dilakukan upaya intensifikasi dan ekstensifikasi dengan mengoptimalkan sumber-sumber pendapatan yang telah ada maupun menggali sumber-sumber baru.

\section{Pendapatan Asli Daerah}

Pendapatan asli daerah merupakan pendapatan yang diperoleh dari sumber- sumber pendapatan daerah dan dikelola sendiri oleh pemerintah daerah. Pendapatan asli daerah diperoleh dan digali dari potensi pendapatan yang ada di daerah.

Menurut Saleh ( 2003 ) Pendapatan daerah merupakan suatu komponen yang sangat menentukan berhasil tidaknya kemandirian Pemerintah kabupaten / kota. Dalam rangka otonomi daerah saat ini. Salah satu komponen yang sangat diperhatikan dalam menentukan tingkat kemandirian daerah dalam rangka otonomi daerah adalah sektor pendapatan asli daerah (PAD).

\section{Leverage}

Leverage merupakan penggunaan sumber - sumber pembiayaan pemerintah daerah, baik yang merupakan sumber pembiayaan jangka pendek maupun sumber pembiayaan jangka panjang. Perlunya leverage yang dapat digunakan untuk meningkatkan pendapatan daerah. Jika tingkat pengembalian atas aktiva lebih besar dari biaya hutang maka leverage tersebut menguntungkan dan hasil yang dicapai untuk peningkatan kesejahteraan pemerintah dapat dicapai. . Namun jika tingkat pengembalian atas aktiva lebih kecil dari biaya hutang maka leverage tersebut akan 
merugikan sehingga dapat mengurangi tingkat pengembalian atas modal. Indikatornya adalah : rasio hutang terhadap aktiva. Rasio hutang terhadap aktiva.

Tingkat rasio hutang terhadap aktiva dapat mengurangi risiko ketidaktepatan profitabilitas. Jika pemerintah daerah memiliki modal yang lebih besar dari hutang maka kinerja keuangan akan berpengaruh secara signifikan dan dapat meningkatkan kesejahteraan.

\section{Kinerja keuangan}

Kinerja keuangan adalah usaha formal yang telah dilakukan pemerintah daerah yang dapat mengukur keberhasilan dalam menghasilkan sumber pendapatan, sehingga dapat melihat prospek, pertumbuhan, dan potensi perkembangan dengan mengandalkan sumber yang ada. Pemerintah daerah dikatakan berhasil jika telah mencapai standar dan tujuan yang telah ditetapkan.

Dalam meningkatkan kinerja keuangan perlunya menetapkan sasaran yang akan dicapai pada masa yang akan datang dalam proses yang disebut perencanaan. Pelaksanaan rencana tersebut memerlukan pengendalian agar efektif dalam mencapai sasaran yang telah ditetapkan. Pengendalian yang dilakukan dapat berupa penilaian kinerja dengan cara menilai dan membandingkan hasil yang dicapai selama periode berjalan. Indikatornya adalah : Pencapaian APBD.

\section{Kerangka Konseptual Penelitian}

Pendapatan asli daerah ( PAD ) terdiri dari pajak daerah, retribusi daerah, pembagian laba BUMD dan penerimaan lain-lain yang sah bukan pajak, sangat mempen dan sebaliknya mempengaruhi kinerja keuangan Pemerintah Daerah. Bila pendapatan asli derah ( PAD ) suatu daerah itu rendah maka persentase PAD untuk membiayai pembangunan rendah,sehingga persentase kemandirian daerah tersebut rendah. Pendapatan asli daerah merupakan semua penerimaan daerah yang berasal dari sumber ekonomi asli daerah.

Kinerja sering diartikan sebagai gambaran setiap hasil ekonomi yang mampu diraih pemerintah daerah pada periode tertentu melalui aktivitas yang dilakukan untuk menghasilkan keuntungan secara efektif, yang dapat diukur perkembangannya dengan mengadakan analisis terhadap datadata keuangan yang tercermin dalam laporan keuangan. Kinerja keuangan adalah tentang melakukan pekerjaan dan hasil yang dicapai dari pekerjaan tersebut. Implementasi kinerja keuangan dilakukan oleh sumber daya manusia yang memiliki kemampuan, kompetensi, motivasi dan kepentingan. Rasio merupakan alat ukur yang digunakan dalam perusahaan untuk menganalisis laporan keuangan. Rasio menggambarkan suatu hubungan atau pertimbangan antara suatu jumlah tertentu dengan jumlah yang lain. Dengan menggunakan alat analisa yang berupa rasio keuangan dapat menjelaskan dan memberikan gambaran kepada penganalisa tentang baik dan buruknya keadaan atau posisi keuangan dari suatu periode ke periode berikutnya.

Ukuran (size) pemerintah daerah, leverage, dan intergovermental revenue berpengaruh terhadap kinerja keuangan pemerintah daerah. Ukuran (size) pemerintah daerah yang diukur dengan total aktiva berpengaruh positif terhadap kinerja keuangan pemerintah daerah. Semakin besar ukuran (size) pemerintah daerah maka semakin baik kinerja keuangan pemerintah daerah tersebut.

Intergovermental revenue juga terbukti berpengaruh terhadap kinerja keuangan pemerintah daerah. Intergovermental revenue merupakan dana yang diberikan pemerintah pusat kepada pemerintah daerah agar digunakan untuk membiayai penyelenggaraan pemerintahan sehingga dapat terlaksanaya pelayanan yang diberikan kepada masyarakat. Dengan demikian, hubungan antara variabel independen ( pendapatan asli daerah, karakteristik ) dengan variabel dependen ( kinerja keuangan ) yang digambarkan dalam bentuk kerangka penelitian. dimaksudkan untuk menjadi penuntun, alur pikir dan landasan untuk menyusun hipotesis. 


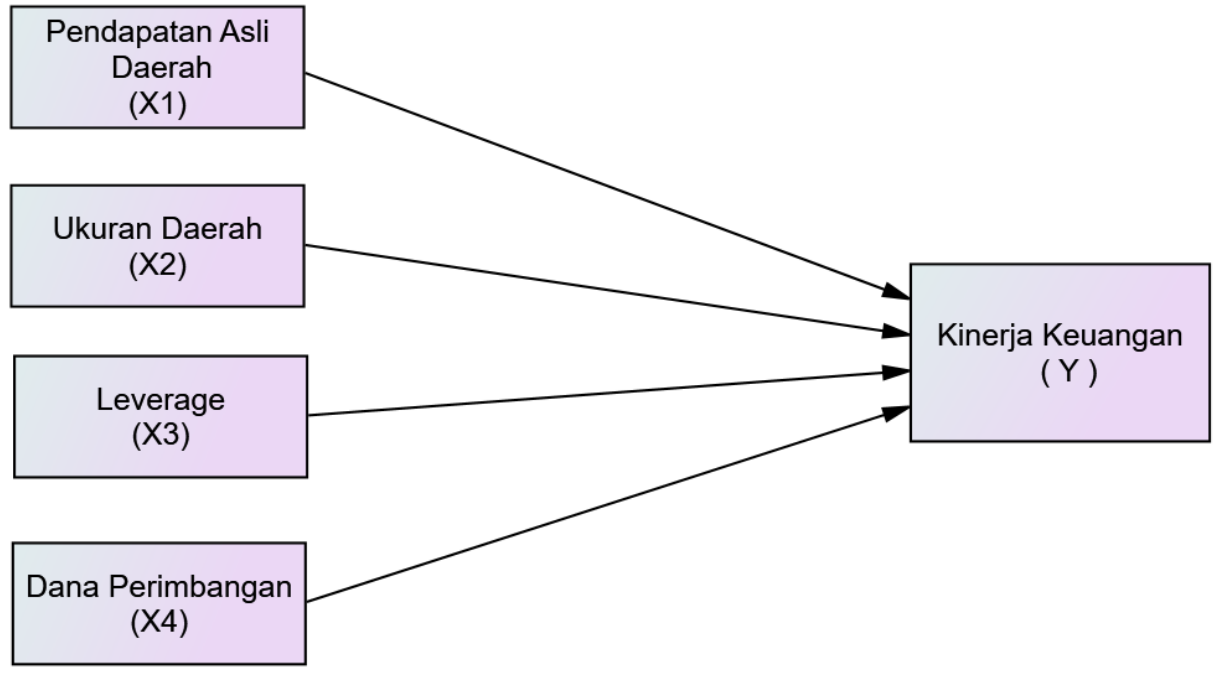

Gambar 1. Kerangka Konseptual

\section{Hipotesis}

\section{Pengaruh pendapatan asli daerah terhadap kinerja keuangan pemerintah daerah}

Pendapatan Asli Daerah (PAD) yang terdiri dari pajak daerah, retribusi daerah, pembagian laba BUMD dan penerimaan lain - lain yang sah bukan pajak, sangat mempengaruhi kinerja keuangan Pemerintah Daerah. Bila PAD suatu daerah itu rendah maka persentase PAD untuk membiayai pelayanan pembangunan rendah, sehingga persentase kemandirian daerah tersebut rendah dan sebaliknya jika PAD suatu daerah itu tinggi maka persentase PAD untuk membiayai pelayanan pembangunan itu tinggi sehingga persentase kemandirian daerah tersebut tinggi. Kinerja keuangan dapat dipakai sebagai alat untuk mengevaluasi kemampuan gambar

Kemampuan pemerintah daerah untuk menghasilkan keuangan daerah melalui penggalian kekayaan asli daerah atau PAD harus terus dipacu pertumbuhannya karena kenaikan PAD akan sangat berpengaruh pada kinerja pemerintah daerah. Kinerja ini dapat dilihat melalui sasaran yang telah tercapai dalam pelaksanaan pembangunan dan pelayanan kepada masyarakat melalui pemanfaatan PAD yang meliputi : pajak daerah, retribusi daerah, hasil perusahaan dan kekayaan daerah, dan lain - lain pendapatan yang sah. Berdasarkan gambar diatas, dapat dikatakan bahwa pendapatan asli daerah adalah variabel independen yang mempunyai pengaruh terhadap kinerja keuangan pemerintah daerah kabupaten / kota Propinsi Papua sebagai variabel dependen. Penelitian mengenai PAD telah dilakukan oleh Indrarti (2011) dan Virgasari (2009) yang mengungkapkan bahwa terdapat korelasi positp antara PAD dan kinerja keuangan. Rumusan hipotesis dalam penelitian ini sebagai berikut :

H1: Pendapatan asli daerah memiliki pengaruh positif terhadap kinerja keuangan pemerintah daerah kabupaten / kota Propinsi Papua.

\section{Pengaruh karakteristik pemerintah daerah terhadap kinerja keuangan pemerintah daerah}

Ukuran (size) pemerintah daerah, leverage, dan dana perimbangan berpengaruh terhadap kinerja keuangan pemerintah daerah. Ukuran ( size) akan berpengaruh terhadap kinerja keuangan. Semakin besar ukuran daerah maka kinerja keuangan akan semakin besar dimana 
jumlah penduduk, jumlah pendapatan daerah akan semakin bertambah, total aset akan semakin besar sehingga kinerja keuangan akan semakin baik.

Penelitian yang dilakukan oleh Kusumawardani ( 2012 ) mengungkapkan bahwa semakin besar ukuran daerah yang dinilai dari semakin besarnya total aset pemerintah daerah akan semakin tinggi pula kinerja pemerintah daerah. Ukuran (size) pemerintah daerah yang diukur dengan total aktiva berpengaruh positif terhadap kinerja keuangan pemerintah daerah.

Semakin besar ukuran (size) pemerintah daerah maka semakin baik kinerja keuangan pemerintah daerah tersebut. Hal tersebut disebabkan pemerintah daerah yang memiliki ukuran besar memiliki tekanan yang besar untuk melakukan pengungkapan atas laporan keuangannya. Pemerintah daerah dalam melakukan pengungkapan atas laporan keuangannya akan lebih terdorong untuk mengungkapkan hal-hal yang bersifat good news. Good news tersebut dapat berupa laporan mengenai baiknya kinerja pemerintah daerah tersebut.

Leverage juga berpengaruh terhadap kinerja keuangan dimana leverage merupakan pinjaman yang diberikan untuk membiayai penyelenggaran program atau kegitan pemerintah daerah dengan tujuan mencapai kesejahteraan masyarakat. Leverage jika dipergunakan dengan baik sesuai pemanfaatannya maka kinerja keuangan yang dihasilkan akan semakin baik. Leverage ikut berperan dalam upaya peningkatan kinerja keuangan karena pemerintah daerah yang memperoleh sumber dan dari hutang dapat meningkatkan kegiatan atau program daerah sehingga dapat juga menghasilkan keuntungan demi mewujudkan peningkatan kinerja keuangan. Menurut Sartono ( 2010 ) mengungkapkan bahwa leverage menunjukan proporsi atas penggunaan hutang untuk membiayai investasinya.

Dana perimbangan juga terbukti berpengaruh terhadap kinerja keuangan pemerintah daerah. Dana perimbangan merupakan dana yang diberikan pemerintah pusat kepada pemerintah daerah agar digunakan untuk membiayai penyelenggaraan pemerintahan sehingga dapat terlaksanya pelayanan yang diberikan kepada masyarakat. Menurut Pattrick ( 2007 ) mengartikan dana perimbangan sebagai salah satu pendapatan pemerintah daerah yang berasal dari transfer dari pemerintah pusat kepada pemerintah daerah untuk membiayai operasi pemerintah daerah. Sebagai timbal baliknya, pemerintah daerah membelanjakan pendapatan transfer antar pemerintah sesuai dengan alokasi dan petunjuk anggaran serta menurut undang - undang.

Berdasarkan uraian diatas, dapat dikatakan bahwa Ukuran ( Size ) daerah, Penggunaan Aktiva / Leverage, Dana perimbangan adalah variabel independen yang mempunyai pengaruh terhadap kinerja keuangan pemerintah daerah Kabupaten / Kota Propinsi Papua sebagai variabel dependen.Rumusan hipotesis dalam penelitian ini sebagai berikut :

H2 : Ukuran ( Size ) daerah memiliki pengaruh positif terhadap kinerja keuangan pemerintah daerah Kabupaten/Kota Propinsi Papua.

H3 : $\quad$ Penggunaan Aktiva/ Leverage terhadap kinerja Keuangan Pemerintah daerah

H4 : Dana Perimbangan / Intergovernmental Revenue terhadap kinerja keuangan pemerintah daerah Kabupaten / Kota Propinsi Papua.

\section{METODOLOGI PENELITIAN}

Pendekatan yang digunakan adalah pendekatan kuantitatif yang bersifat deduktif dengan menggunakan struktur teori untuk membentuk hipotesis dan kemudian menggunakan fakta atau data empiris untuk menguji hipotesis sehingga mendapatkan kesimpulan atau konklusif ( Jogiyanto, 2004 ). Penelitian dilaksanakan pada Pemerintah Kab / Kota Propinsi sebanyak 26.Kabupaten / Kota . Waktu penelitian selama 3 bulan yaitu mulai tanggal 13 juni $2014-22$ september 2014. Sedangkan populasi penelitian ini adalah kabupaten / kota Propinsi Papua sebanyak 26. Populasi adalah wilayah generalisasi yang terdiri atas obyek / subyek yang mempunyai kualitas dan karakteristik tentang apa yang ditetapkan oleh peneliti untuk dipelajari dan kemudian ditarik kesimpulan ( Sugiyono, 2007 ). Sampel adalah bagian dari jumlah dan karakteristik yang dimiliki oleh populasi ( Sugiyono, 2007 ). Sampel yang digunakan dalam 
penelitian ini menggunakan metode sensus sebanyak 12 kabupaten/kota Propinsi Papua. Kegiatan menganalisis data dalam penelitian meliputi beberapa tahap yaitu :

1. Proses editing; tahap awal analisis data adalah melakukan edit terhadap data yang telah dikumpulkan. Pada prinsipnya proses editing data bertujuan agar data yang nanti akan dianalisis telah akurat dan lengkap.

2. Tabulasi; menyajikan data - data yang diperoleh dalam table, sehingga diharapkan dapat melihat hasil penelitian dengan jelas.Setelah proses tabulasi selesai kemudian data- data dalam table tersebut analisa dengan bantuan komputer program statistic SPSS Windows versi 25 .

Tabel 1. Definisi Operasional dan Pengukurannya

\begin{tabular}{|c|c|c|c|c|}
\hline Variabel & Definisi & Indikator & Sumber & Skala \\
\hline $\begin{array}{l}\text { Pendapatan Asli } \\
\text { Daerah } \\
\text { ( X1 ) }\end{array}$ & $\begin{array}{l}\text { Pendapatan merupakan } \\
\text { penambahan kas } \\
\text { pemerintah pusat yang } \\
\text { berasal dari berbagai } \\
\text { sumber antara lain } \\
\text { mencakup penerimaan } \\
\text { pajak dan cukai, } \\
\text { penerimaan pendapatan } \\
\text { yang berasal dari } \\
\text { investasi, penerimaan } \\
\text { pinjaman luar negeri, } \\
\text { dan pinjaman dalam } \\
\text { negeri dan hibah. }\end{array}$ & $\begin{array}{l}\text { Peningkatan } \\
\text { PAD }\end{array}$ & $\begin{array}{l}\text { Wihardi } \\
\text { ( } 1992 \text { ) }\end{array}$ & Rasio \\
\hline $\begin{array}{l}\text { Karakteristik } \\
\text { Pemeritah } \\
\text { Daerah } \\
\text { ( X2 ) }\end{array}$ & $\begin{array}{l}\text { Karakteristik } \\
\text { merupakan porsi total } \\
\text { aset, porsi pendapatan } \\
\text { asli daerah terhadap } \\
\text { total pendapatan, porsi } \\
\text { dana alokasi umum } \\
\text { terhadap total } \\
\text { pendapatan, total } \\
\text { belanja daerah,jumlah } \\
\text { anggota legislatif. }\end{array}$ & & $\begin{array}{l}\text { Suhardjanto et } \\
\text { al. (2010) }\end{array}$ & Rasio \\
\hline $\begin{array}{c}\text { 1. Ukuran } \\
\text { daerah }\end{array}$ & $\begin{array}{l}\text { Jika ukuran daerah } \\
\text { semakin luas maka } \\
\text { asset yang dimiliki } \\
\text { lebih besar sehingga } \\
\text { kinerja keuangan akan } \\
\text { semakin baik }\end{array}$ & Luas wilayah & $\begin{array}{l}\text { Cooke } \\
\text { ( } 1992 \text { ) }\end{array}$ & \\
\hline 2. Leverage & 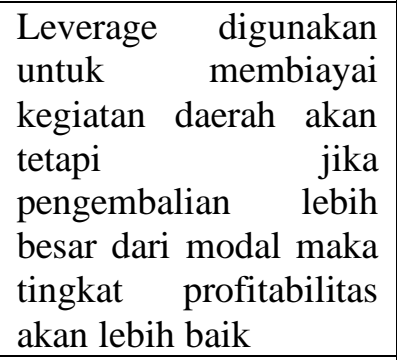 & $\begin{array}{ll}\text { Rasio } & \text { Hutang } \\
\text { terhadap } & \\
\text { Aktiva } & \end{array}$ & $\begin{array}{l}\text { Cohen } \\
(2008)\end{array}$ & \\
\hline $\begin{array}{l}\text { 3.Dana } \\
\text { Perimbangan }\end{array}$ & $\begin{array}{l}\text { Dana transfer dari } \\
\text { pemerintah pusat ke } \\
\text { pemerintah daerah } \\
\text { dapat digunakan untuk } \\
\text { membiayai regatan }\end{array}$ & $\begin{array}{l}\text { Dana transfer } \\
\text { dari } \\
\text { pemerintah } \\
\text { Pusat }\end{array}$ & $\begin{array}{l}\text { Patrick } \\
\text { ( 2007 ) }\end{array}$ & \\
\hline
\end{tabular}




\begin{tabular}{|c|c|c|c|}
\hline & $\begin{array}{lr}\text { daerah sehingga } \\
\text { pertumbuhan ekonomi } \\
\text { daerah lebih baik akan } \\
\text { tetapi diharapkan } \\
\text { pemerintah daerah } \\
\text { mengurangi sifat } \\
\text { ketergantungan kepada } \\
\text { pemerintah pusat }\end{array}$ & & \\
\hline $\begin{array}{l}\text { 3. Kinerja } \\
\text { Keuangan }\end{array}$ & \begin{tabular}{lr}
\multicolumn{2}{l}{ kinerja keuangan dapat } \\
dipakai sebagai alat \\
untuk mengevaluasi \\
kemampuan \\
pemerintah & dalam \\
kemandirian & daerah \\
otonomi & melalui \\
sasaran yang & telaah \\
dicapai & dalam \\
pelaksanaan & \\
pembangunan & dan \\
pelayanan & kepada \\
masyarakat &
\end{tabular} & $\begin{array}{l}\text { Pencapaian } \\
\text { APBD }\end{array}$ & $\begin{array}{l}\text { Hamzah } \\
(2009\end{array}$ \\
\hline
\end{tabular}

ANALISA HASIL

\section{Deskripsi Data}

\section{Tabel 1}

Statistik Deskriptif Variabel

Descriptive Statistics

\begin{tabular}{|l|l|l|l|l|l|}
\hline & $\mathrm{N}$ & Minimum & Maximum & Mean & Std. Deviation \\
\hline Kinerja & 36 & 1.00 & 1.39 & 1.0742 & .08823 \\
LnX1 & 36 & 8.16 & 11.58 & 9.3230 & .90205 \\
LnX2 & 36 & 9.45 & 12.16 & 11.1114 & .84998 \\
Leverage & 36 & .00 & .06 & .0106 & .01722 \\
LnX4 & 36 & 11.26 & 13.85 & 13.2239 & .39520 \\
Valid N & 36 & & & & \\
(listwise) & & & & & \\
\hline
\end{tabular}

Berdasarkan tabel 1 dapat diketahui bahwa kinerja keuangan pemerintah daerah kabupaten/kota propinsi Papua memiliki rerata sebesar 1,0742. Nilai rerata sebesar 1,0742 berarti bahwa pemerintah daerah kabupaten/kota Propinsi Papua tergolong memiliki kinerja yang baik. Penelitian yang dilakukan Hamzah (2009) mengungkapkan apabila pemerintah daerah yang memiliki persentase kinerja keuangan sebesar 90 - 100 maka pemerintah daerah tersebut kurang memiliki kinerja keuangan yang baik.

Dilihat dari pendapatan asli daerah kabupaten / kota Propinsi Papua memiliki rerata sebesar LnX1 9,32 (18,248), total PAD terendah sebesar 8,16 (3.482), sementara PAD tertinggi sebesar 11,58 (106.520). Ukuran daerah memiliki rerata sebesar 11.11 (89.614). ukuran daerah terendah sebesar 9.45 (12.713), serta ukuran daerah tertinggi sebesar 12.16 (191.099). Leverage memiliki rerata sebesar 0.016, sedangkan leverage terendah sebesar 0,00 dan leverage tertinggi sebesar 0,06. Dana perimbangan memiliki rerata sebesar 13.22 (584.336), sedangkan dana perimbangan terendah sebesar 11.26, dana perimbangan tertinggi sebesar 13.85 .

\section{Pengujian Asumsi Klasik}


Uji asumsi klasik bertujuan untuk melihat ada tidaknya penyimpangan klasik dari data variabel penelitian diantaranya uji asumsi klasik yaitu :

\section{Uji Heterokedastisitas}

Uji heterokedastisitas adalah asumsi dalam regresi dimana varians dari residual tidak sama untuk satu pengamatan ke pengamatan lain dimana dari hasil output dapat diketahui bahwa grafik plot (Scatterplot) tidak terdapat pola yang jelas dan tidak membentuk pola tertentu yang teratur, maka dapat dikatakan bahwa tidak terjadi heterokedastisitas.

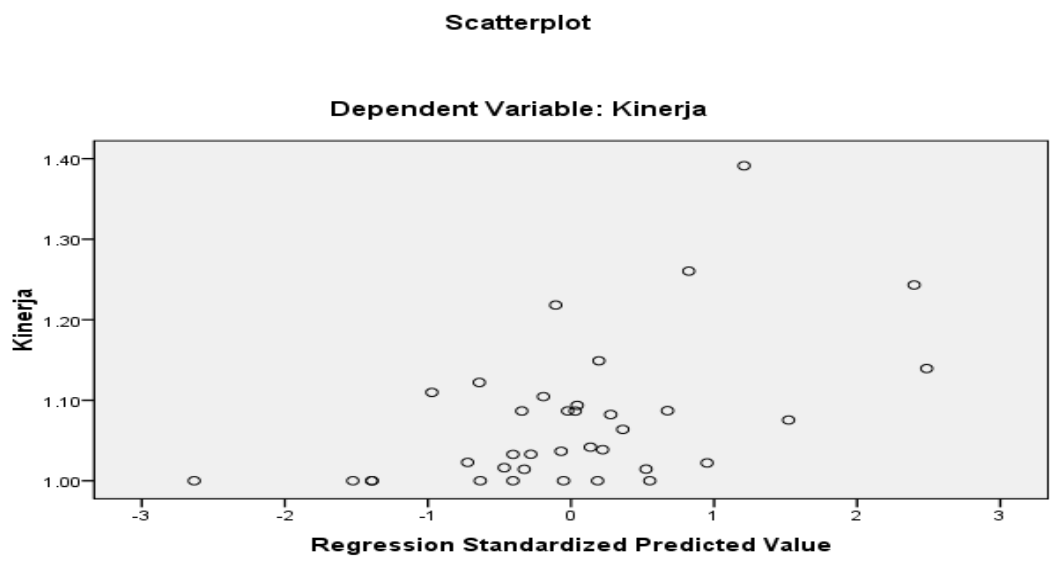

Gambar 3. Hasil Pengujian Heterokedastisitas ( Lampiran 5 )

\section{Uji Normalitas}

Uji normalitas data bertujuan untuk menguji apakah dalam model regresi,variabel terikat dan variabel bebas keduanya mempunyai distribusi normal atau tidak. Hasil uji normalitas menunjukkan bahwa data penelitian telah teredistribusi normal yang dibuktikan dengan asymp sig. sebesar 0,297 yang lebih besar dari tingkat signifikansi penelitian 0,05.

Pengujian normalitas lainnya dilakukan dengan melihat dari histogram dan Regression Standardized Residual dan menggunakan normal probability plot, adapun grafik hitogram dapat dilihat sebagai berikut :

\section{Tabel 2}

Uji Normalitas Data

One-Sample Kolmogorov-Smirnov Test

\begin{tabular}{|ll|l|}
\hline & & $\begin{array}{l}\text { Standardized } \\
\text { Residual }\end{array}$ \\
\hline $\mathrm{N}$ & & 36 \\
Normal Parameters ${ }^{\mathrm{a}}$ & Mean & .0000000 \\
& Std. Deviation & .94112395 \\
Most Extreme Differences Absolute & .163 \\
& Positive & .163 \\
& Negative & -.094 \\
Kolmogorov-Smirnov Z & .976 \\
Asymp. Sig. (2-tailed) & .297 \\
\hline a. Test distribution is Normal. & \\
\hline
\end{tabular}

Sumber : ( Lampiran ) 
Gambar 1

Histogram

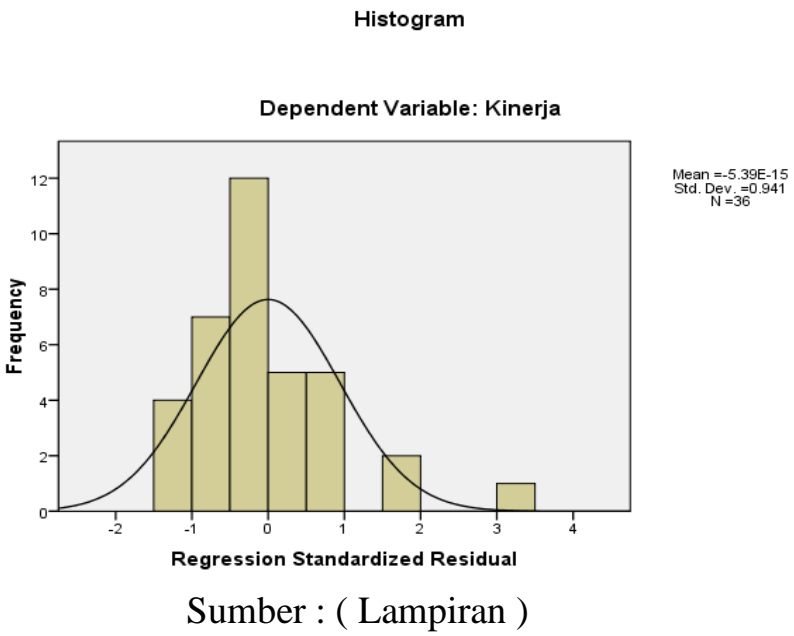

\section{Uji Multikolinearitas}

Dari hasil pengujian multikolinearitas data dapat diketahui nilai variance Inflation factor ( VIF ) keempat variabel bebas yaitu : pendapatan asli daerah sebesar 1,557, ukuran daerah $(\operatorname{LnX2)}$ sebesar 1,600, leverage (X3) sebesar 1,047, dana perimbangan $(\operatorname{Ln}(X 4)$ sebesar 1.010 dimana keeempat variabel tersebut mempunyai nilai VIF lebih kecil dari 10,dan nilai toleransinya lebih besar dari 0,1.Hal ini menunjukan bahwa indikasi keberadaan multikolinearitas pada persamaan yang dilakukan atau hubungan yang terjadi antara variabel dalam pendapatan asli daerah,ukuran daerah,leverage,dana perimbangan dapat ditoleransi sehingga tidak akan mengganggu hasil regresi.

Tabel 3.

Hasil Pengujian Multikolinearitas

\begin{tabular}{|c|c|c|c|}
\hline Variabel & Toleransi & VIF & Keterangan \\
\hline X1: PAD & 0.642 & 1.557 & \multirow{4}{*}{$\begin{array}{l}\text { Tidak } \\
\text { terdapat } \\
\text { multikolinearitas }\end{array}$} \\
\hline X2: Ukuran daerah & 0.625 & 1.600 & \\
\hline X3 :Leverage & 0.955 & 1.047 & \\
\hline X4:Dana Perimbangan & 0.991 & 1.010 & \\
\hline
\end{tabular}

Sumber : Hasil olahan data,2013 ( Lampiran 5 )

\section{Hasil Analisis Regresi Berganda}

Analisis regresi linear berganda (multiple regression) dilakukan untuk menganalisis pengaruh antara variabel bebas terhadap variabel terikat,baik secara parsial maupun simultan serta untuk menguji hipotesis penelitian yang telah dikemukakan sebelumnya. Hasil perhitungan dengan menggunakan SPSS 16.00 for Windows adalah sebagai berikut :

\section{Koefisien Determinasi}

Koefisien Determinasi ( $\mathrm{R}^{2}$ ) digunakan untuk mengetahui seberapa besar pengaruh variabel bebas ( pendapatan asli daerah, ukuran daerah, leverage, dana perimbangan ) terhadap variabel terikat. 
Tabel 5

Hasil analisis Determinasi Simultan

Model Summary ${ }^{\mathrm{b}}$

\begin{tabular}{|l|l|l|l|l|l|}
\hline Model & $\mathrm{R}$ & $\mathrm{R}$ Square & $\begin{array}{l}\text { Adjusted } \\
\text { Square }\end{array}$ & $\begin{array}{l}\text { R } \\
\text { Std. Error of the } \\
\text { Estimate }\end{array}$ & $\begin{array}{l}\text { Durbin- } \\
\text { Watson }\end{array}$ \\
\hline 1 & $.518^{\mathrm{a}}$ & .269 & .174 & .08017 & 1.803 \\
\hline
\end{tabular}

a. Predictors: (Constant), LnX4, LnX1, Leverage, LnX2

b. Dependent Variable: Kinerja

Sumber : Hasil Olahan Data,2014

Tabel 5 memperlihatkan bahwa korelasi antara pendapatan asli daerah, ukuran daerah, leverage, dana perimbangan terhadap kinerja keuangan pemerintah kabupaten/kota Propinsi Papua diperoleh nilai koefisien korelasi $\mathrm{R}=0,518$ berarti ada hubungan positif dan kuat antara pendapatan asli daerah, ukuran daerah, leverage, dana perimbangan terhadap kinerja keuangan pemerintah daerah kabupaten/kota Propinsi Papua.

Nilai R-Square dari regresi menunjukan bahwa koefisien determinasi yang ditunjukan dari nilai R-Square ( $\left.R^{2}\right)$ sebesar 0,269 hal ini berarti $26,9 \%$ variasi kinerja pemerintah kabupaten / kota Propinsi Papua dapat dijelaskan oleh variasi dari keempat variabel independen yaitu pendapatan asli daerah, ukuran daerah, leverage, dana perimbangan sedangkan sisanya $(100 \%-26.9 \%=$ $73,4 \%$ ) dijelaskan oleh faktor lain yang tidak diteliti dalam penelitian ini.

\section{Uji Signifikansi Simultan (Uji Statistik F )}

Pengujian hipotesis uji F digunakan untuk melihat apakah secara keseluruhan variabel bebas mempunyai pengaruh yang bermakna terhadap variable terikat.Dari hasil pengujian simultan diperoleh sebagai berikut :

Tabel 6. Hasil Pengujian Simultan ( Uji F )

ANOVA ${ }^{\mathbf{b}}$
\begin{tabular}{|ll|l|l|l|l|l|} 
Model & $\begin{array}{l}\text { Sum } \\
\text { Squares }\end{array}$ & of & Df & $\begin{array}{l}\text { Mean } \\
\text { Square }\end{array}$ & F & Sig. \\
\hline 1 & Regression & .073 & 4 & .018 & 2.848 & $.040^{\mathrm{a}}$ \\
& Residual & .199 & 31 & .006 & & \\
\multicolumn{1}{|c|}{ Total } & .272 & 35 & & & \\
\hline
\end{tabular}

a. Predictors: (Constant), LnX4, LnX1, Leverage, LnX2

b. Dependent Variable: Kinerja

Sumber : Hasil Olahan Data,2014

Tabel 6 menunjukan hasil perhitungan statistik uji $\mathrm{F}$ sebesar 2,848 dengan probabilitas 0.040. Probabilitas jauh lebih kecil dari 0,05 yang berarti secara simultan seluruh variabel independen yaitu pendapatan asli daerah, ukuran daerah, leverage, dana perimbangan berpengaruh signifikan terhadap variabel kinerja keuangan pemerintah kabupaten / kota Propinsi Papua.

Hal ini dapat diketahui dari nilai $\mathrm{F}$ - hitung $>\mathrm{F}$ - tabel yakni 2,848 diperoleh dari $\mathrm{df}=31$ dan $\alpha=0,05$. Dengan demikian model regresi ini dapatmenjelaskan yaitu pendapatan asli daerah, ukuran daerah, leverage, dana perimbangan secara bersama - sama berpengaruh terhadap kinerja pemerintah daerah kabupaten / kota Propinsi Papua. 


\section{Uji Signifikansi parsial ( Uji t )}

Pengujian hipotesis secara parsial digunakan untuk melihat menentukan pengaruh masing masing variable bebas terhadap variable terikat,yaitu pendapatan asli daerah, ukuran daerah, leverage, dana perimbangan terhadap kinerja keuangan pemerintah daerah kabupaten/kota Propinsi Papua. Hasil pengujiannya dapat dilihat melalui nilai $\mathrm{t}$ - hitungnya , sedangkan untuk melihat besarnya pengaruh digunakan koefisien regresi.

Tabel 7. Hasil Pengujian Uji Signifikansi Parsial ( Uji T )

Coefficients $^{\mathrm{a}}$

\begin{tabular}{|c|c|c|c|c|c|c|c|}
\hline \multirow[b]{2}{*}{ Model } & \multicolumn{2}{|c|}{$\begin{array}{l}\text { Unstandardize } \\
\text { d Coefficients }\end{array}$} & \multirow{2}{*}{\begin{tabular}{|l}
$\begin{array}{l}\text { Standardized } \\
\text { Coefficients }\end{array}$ \\
Beta
\end{tabular}} & \multirow[b]{2}{*}{$\mathrm{t}$} & \multirow[b]{2}{*}{ Sig. } & \multicolumn{2}{|c|}{ Collinearity Statistics } \\
\hline & B & $\begin{array}{l}\text { Std. } \\
\text { Error }\end{array}$ & & & & Tolerance & VIF \\
\hline 1 (Constant) & .436 & .482 & & .905 & .373 & & \\
\hline LnX1 & .041 & .019 & .417 & 2.176 & .037 & .642 & 1.557 \\
\hline LnX2 & -.012 & .020 & -.112 & -.579 & .567 & .625 & 1.600 \\
\hline Leverage & $\overline{1}-652$ & .805 & -.322 & -2.052 & .049 & .955 & 1.047 \\
\hline LnX4 & .031 & .034 & .137 & .890 & .380 & .991 & 1.010 \\
\hline
\end{tabular}

a. Dependent Variable:

Sumber : Olahan Data ( lampiran )

Tabel di atas menunjukkan pengaruh masing-masing variabel bebas yang terdiri atas pendapatan asli daerah, ukuran daerah, leverage, dan dana perimbangan terhadap kinerja pemerintah daerah kabupaten/kota Propinsi Papua yang dimasukkan dalam model persamaan regresi berganda sebagai berikut :

\section{$Y=0,436+0,041 \times 1-0,012 \times 2-1,652 X 3+0,031$ X4}

Berdasarkan hasil persamaaan tersebutdiatas dapat dijelaskan sebagai berikut :

a. Nilai konstanta (b0) sebesar 0,436, hal ini dapat diartikan bahwa jika tidak ada perubahan pada pendapatan asli daerah, ukuran daerah, leverage, dan dana perimbangan, maka kinerja keuangan kabupaten/kota propinsi papua sebesar 0,436.

b. Nilai koefisien regresi (b1) variable pendapatan asli daerah (X1 ) sebesar 0,041, hal ini dapat dapat diartikan bahwa jika terjadi peningkatan PAD, maka akan menyebabkan peningkatan terhadap kinerja keuangan kabupaten/kota Propinsi Papua sebesar 0.041 .

c. Nilai koefisien regresi ( b2 ) variable ukuran daerah ( X2 ) sebesar -0,012 hal ini dapat diartikan bahwa jika terjadi peningkatan peningkatan ukuran daerah maka akan menyebabkan penurunan terhadap kinerja keuangan kabupaten/kota Propinsi Papua sebesar 0,012 .

d. Nilai koefisien regresi ( b3 ) variable leverage( X3 ) sebesar -1,652 hal ini dapat diartikan bahwa jika terjadi peningkatan pada rasio leverage maka akan menyebabkan penurunan terhadap kinerja keuangan kabupaten/kota Propinsi Papua sebesar 1,652.

e. Nilai koefisien regresi ( b4 ) variable dana perimbangan( X4 ) sebesar 0,031, hal ini dapat diartikan bahwa jika terjadi peningkatan peningkatan dana perimbangan maka akan menyebabkan peningkatan terhadap kinerja keuangan kabupaten/kota Propinsi Papua sebesar 0,031 . 
Berdasarkan uraian diatas dapat diketahui bahwa dari keempat variabel yang diteliti ada dua variabel yang berpengaruh positif yaitu pendapatan asli daerah (X1) dan dana perimbangan (X4) dan dua variabel bebas yang berpengaruh negatif terhadap kinerja keuangan yaitu ukuran (X2) dan leverage (X3), ternyata variable leverage (X3 ) yang mempunyai pengaruh dominan dalam meningkatkan kinerja keuangan pemerintah kabupaten/kota Propinsi Papua, sebab diperoleh angka keofisen regresi sebesar -1,652 yang lebih besar dari variable lain.

\section{Hasil pengujian Hipotesis}

Berdasarkan pada hasil analisis sebelumnya sudah dapat diketahui pengaruh masing - masing variabel bebas yang terdiri atas pengaruh pendapatan asli daerah, ukuran daerah, leverage, dana perimbangan terhadap kinerja keuangan pemerintah daerah kabupaten/kota Propinsi Papua. Selanjutnya hasil pengujian hipotesis penelitian dapat dijelaskan sebagai berikut :

1. Hipotesis $1(\mathrm{H} 1)$ pendapatan asli daerah berpengaruh terhadap kinerja keuangan kabupaten/kota Propinsi Papua diterima, hal ini disebabkan karena secara statistik nilai $\mathrm{p}=0,037$ lebih kecil dari alpha $0,05(0,037<0,05)$, hal ini memberikan makna bahwa secara statistik pendapatan asli daerah berpengaruh positif dan signifikan terhadap kinerja keuangan pemerintah kabupaten/kota Propinsi Papua.

2. Hipotesis $2(\mathrm{H} 2)$ Ukuran daerah berpengaruh terhadap kinerja keuangan pemerintah daerah kabupaten/kota Propinsi Papua ditolak, hal ini disebabkan karena secara statistik nilai $\mathrm{p}=0,567$ lebih besar dari alpha $0,05(0,567>0,05)$, hal ini memberikan makna bahwa secara statistik ukuran daerah berpengaruh negatif dan tidak signifikan terhadap kinerja keuangan pemerintah kabupaten / kota Propinsi Papua.

3. Hipotesis $3(\mathrm{H} 3)$ leverage berpengaruh terhadap kinerja keuangan pemerintah daerah kabupaten/kota Propinsi Papua diterima, hal ini disebabkan karena secara statistik nilai $\mathrm{p}=0,049$ lebih kecil dari alpha $0,05(0,049<0,05)$, hal ini memberikan makna bahwa secara statistik leverage berpengaruh negatif dan signifikan terhadap kinerja keuangan pemerintah kabupaten/kota Propinsi Papua.

4. Hipotesis $4(\mathrm{H} 4)$ dana perimbangan berpengaruh terhadap kinerja keuangan pemerintah daerah kabupaten/kota Propinsi Papua ditolak, hal ini disebabkan karena secara statistik nilai $p=0,380$ lebih besar dari alpha $0,05(0,380>0,05)$, hal ini memberikan makna bahwa secara statistik dana perimbangan berpengaruh positif dan tidak signifikan terhadap kinerja keuangan pemerintah kabupaten/kota Propinsi Papua.

\section{PEMBAHASAN}

\section{Pengaruh PAD terhadap kinerja keuangan.}

Pendapatan asli daerah merupakan pendapatan yang diperoleh dari sumber- sumber pendapatan daerah dan dikelola sendiri oleh pemerintah daerah. Pendapatan asli daerah diperoleh dan digali dari potensi pendapatan yang ada di daerah.

Menurut Saleh ( 2003 ) Pendapatan daerah merupakan suatu komponen yang sangat menentukan berhasil tidaknya kemandirian Pemerintah kabupaten / kota. Dalam rangka otonomi daerah saat ini. Salah satu komponen yang sangat diperhatikan dalam menentukan tingkat kemandirian daerah dalam rangka otonomi daerah adalah sektor pendapatan asli daerah ( PAD ).

Hasil penelitian menunjukkan bahwa pendapatan asli daerah berpengaruh signifikan terhadap kinerja keuangan pemerintah kabupaten/kota Propinsi Papua, ini dibuktikan berdasarkan hasil pengujian hipotesis yang menyatakan bahwa pendapatan asli daerah berpengaruh signifikan terhadap kinerja keuangan pemerintah kabupaten/kota Propinsi Papua diterima, hal ini memberikan makna bahwa secara statistik pendapatan asli daerah berpengaruh siginifikan terhadap kinerja keuangan pemerintah kabupaten/kota Propinsi Papua. 
Temuan ini sejalan yang dilakukan oleh M. Yusuf Indrawan (2013), Ratna Ayu \& Nirwana (2013) menyatakan pendapatan asli daerah berpengaruh terhadap kinerja keuangan pemerintah daerah pada pemerintah kabupaten/kota se-Provinsi Sulawesi Selatan tahun 2009-2011 dengan nilai signifikansi sebesar 0,000 dimana nilai tersebut kurang dari $\alpha=0,05(0,000<0,05)$. Pengaruh PAD terhadap kinerja keuangan pemerintah daerah, yaitu dengan meningkatnya PAD yang digunakan untuk membiayai pembangunan dan pelayanan publik maka semakin baik kinerja keuangan pemerintah daerah.

Lebih lanjut temuan di dukung oleh temuan yang dilakukan yusron barnawi (2013) menemukan Hasil dari penelitian ini menunjukkan bahwa Pendapatan Asli Daerah (PAD), Belanja Modal dan Jumlah Penduduk berpengaruh positif terhadap kinerja keuangan pemerintah daerah Kabupaten/Kota di Jawa Tengah dan Daerah Istimewa Yogyakarta.

\section{Pengaruh Ukuran Daerah Terhadap Kinerja Keuangan}

variabel ukuran daerah ( size ) yang diukur dengan menggunakan total jumlah penduduk dan luas daerah. Berdasarkan penggunaan uji regresi berganda dengan menggunakan metode regresi berganda maka dapat terlihat bahwa ukuran (size) daerah kabupaten / kota Propinsi Papua tidak berpengaruh signifikan terhadap kinerja keuangan karena (1) masih terdapat daerah daerah yang sulit dijangkau menggunakan transportasi, (2) masih kurangnya kemampuan masyarakat dalam mengelola sumber alam yang ada sehingga menyebabkan tingkat kemiskinan yang sangat tinggi, (3) masyarakat masih sangat bergantung dari dana otsus yang diberikan pemerintah pusat oleh sebab itu tingkat kemandirian pemerintah daerah kabupaten / kota propinsi papua masih kurang dan kinerja keuangan yang diharapkan kurang memadai.

Berdasarkan koefisien regresi untuk variabel ukuran ( size) adalah negatif yang mengindikasikan bahwa semakin besar ukuran suatu pemerintah maka semakin rendah kinerja keuangan pemerintah daerah tersebut. Penelitian yang dilakukan oleh Cooke ( 1992 ) mengungkapkan bahwa entitas yang memiliki ukuran yang lebih besar akan memiliki tekanan yang lebih besar pula dari untuk melakukan pengungkapan.

Besarnya tuntutan publik untuk melakukan pengungkapan akan berdampak pula pada tuntutan kinerja yang dimiliki entitas tersebut. Pemerintah daerah akan cenderung akan memberikan Good news dalam mengungkapkan laporan keuangannya.Good News tersebut dapat berupa laporan mengenai baiknya kinerja pemerintah daerah tersebut. Hasil penelitian ini berbeda dengan penelitian yang dilakukan Ramasamy, Ong, dan Yeung (2005) yang menyatakan bahwa terdapat pengaruh positip antara ukuran daerah terhadap kinerja suatu entitas.

\section{Pengaruh Leverage terhadap kinerja keuangan}

Berdasarkan penggunaan uji regresi berganda dengan menggunakan metode regresi berganda maka dapat terlihat bahwa variable leverage menunjukan berpengaruh signifikan negartif terhadap kinerja keuangan. Hal tersebut mengartikan bahwa semakin besar leverage suatu pemerintah daerah maka kinerja keuangan yang dimiliki pemerintah daerah tersebut akan semakin berkurang,

Hasil penelitian ini didukung oleh penelitian yang dilakukan oleh Choiriyah (2010) mengungkapkan bahwa leverage merupakan proporsi total hutang terhadap rata - rata ekuitas. Lebih lanjut Perwitasari ( 2010 ) mengungkapkan bahwa pemerintah daerah yang memiliki leverage yang tinggi maka memiliki kinerja yang buruk karena sumber pendanaan utamanya berasal dari pihak eksternal.

Sudarmadji dan Sularto (2007) mengungkapkan bahwa leverage adalah ukuran yang digunakan dalam mengetahui besarnya aktiva yang dibiayai dengan hutang. Lebih lanjut, hutang dalam hal ini berasal dari pihak kreditor dan bukan berasal dari investor atau pemegang saham. Leverage menggambarkan struktur modal yang dimiliki perusahaan. 
Penelitian yang dilakukan Cohen and Kaimenakis (2008) mengungkapkan bahwa entitas yang memiliki leverage tinggi akan mendapat pengawasan lebih dari kreditor. Salah satu cara pengawasan yang dilakukan kreditor terhadap pemerintah daerah adalah melalui pengawasan kegiatan yang dilakukan pemerintah daerah tersebut. Dalam pelaksanaan kegiatannya, entitas membutuhkan persetujuan kreditor atas kegiatan yang dilakukannya (Haniffa and Cooke,2005).

Pengawasan kreditor terhadap pemerintah daerah akan berdampak terhadap semakin baiknya kinerja keuangan pemerintah daerah tersebut. Pemerintah daerah harus dapat menjamin dan meyakinkan kreditor bahwa dana yang dipinjamnya dapat terbayarkan. Hal ini sejalan dengan penelitian yang dilakukan Pattrick (2007) yang mengungkapkan bahwa kreditor akan mengawasi aktivitas pemerintah daerah agar mendapat jaminan bahwa pemerintah daerah akan membayar atas dana yang dipinjamnya.

\section{Pengaruh Dana Perimbangan terhadap Kinerja keuangan}

Tanda koefisien regresi untuk variabel dana perimbangan adalah tidak berpengaruh signifikan terhadap kinerja keuangan. Hal ini disebabkan masih belum tersalurkannya dana transfer yang diberikan pemerintah pusat terhadap pembangunan yang ada di pemerintah kabupaten / kota propinsi Papua sehingga program pembangunan belum terlaksana dengan baik. Besarnya dana perimbangan menunjukan bahwa tersedianya dana yang dapat digunakan pemerintah daerah untuk membiayai penyelenggaraan pemerintahan.

Terlaksananya pemerintahan dapat berimplikasi yang diberikan kepada masyarakat. Pemerintah pusat berharap dengan adanya transfer dana tersebut maka pelayanan yang diberikan kepada masyarakat dapat lebih baik.

5. Pengaruh Pendapatan Asli Daerah, Ukuran Daerah Daerah, Leverage, dan Dana Primbangan Terhadap Kinerja Keuangan.

Kebijakan desentralisasi ditujukan untuk mewujudkan kemandirian daerah, Pemerintah Daerah mempunyai kewenangan untuk mengatur dan mengurus kepentingan masyarakat setempat menurut prakarsa sendiri berdasar aspirasi masyarakat (UU 32/2004). Kemampuan daerah untuk menyediakan pendanaan yang berasal dari daerah sangat tergantung pada kemampuan merealisasikan potensi ekonomi tersebut menjadi bentuk-bentuk kegiatan ekonomi yang mampu menciptakan perguliran dana untuk pembangunan daerah yang berkelanjutan.

Hasil penelitian menunjukkan secara simultan pendapatan asli daerah, ukuran daerah, leverage, dan dana perimbangan berpengaruh signifikan terhadap terhadap kinerja keuangan Pemerintah Daerah Kabupaten/Kota Propinsi Papua.

Temuan ini sejalan dengan temuan Hedro Sumarjo (2010) Judul Pengaruh Karakteristik Pemerintah Daerah Terhadap Kinerja Keuangan Pemerintah Daerah (Studi Empiris pada Pemerintah Daerah Kabupaten/Kota di Indonesia). Hasil penelitian ini menjelaskan bahwa, karakteristik pemerintah daerah (ukuran (size) pemerintah daerah, kemakmuran (wealth), ukuran legislatif, leverage, dan intergovermental revenue) secara simultan terhadap kinerja keuangan pemerintah daerah Kabupaten/Kota di Indonesia.

\section{KESIMPULAN DAN SARAN}

\section{Kesimpulan}

1. Berdasarkan hasil pengujian hipotesis dapat diketahui pendapatan asli daerah berpengaruh signifikan terhadap kinerja keuangan pemerintah daerah Kabupaten/Kota Propinsi Papua.

2. Berdasarkan hasil pengujian hipotesis dapat diketahui ukuran daerah tidak berpengaruh signifikan terhadap kinerja keuangan pemerintah daerah Kabupaten/Kota Propinsi Papua. 
3. Berdasarkan hasil pengujian hipotesis dapat diketahui leverage berpengaruh negatif signifikan terhadap keuangan pemerintah daerah Kabupaten/Kota Propinsi Papua.

4. Berdasarkan hasil pengujian hipotesis dapat diketahui dana perimbangan tidak berpengaruh signifikan terhadap kinerja keuangan pemerintah daerah Kabupaten/Kota Propinsi Papua.

5. Berdasarkan hasil uji simultan dapat diketahui pendapatan asli daerah, ukuran daerah, leverage dan dana perimbangan secara bersama-sama berpengaruh signifikan terhadap kinerja keuangan pemerintah daerah Kabupaten/Kota Propinsi Papua.

\section{Saran}

Hasil simpulan diatas menjadi dasar bagi peneliti untuk mengajukan saran bagi pemerintah daerah kabupaten / kota Propinsi Papua untuk dapat lebih meningkatkan kinerja keuangannya.

1. Diharapkan Pemerintah daerah dapat menggali potensi yang ada di daerahnya sehingga dapat membiayai kegiatannnya dari sumber pendapatan asli daerah, adanya kesadaran kepada masyarakat akan pentingnya membayar pajak dan retribusi sehingga pendapatan daerah mengalami peningkatan, adanya kesadaran sikap untuk tidak bergantung kepada pemerintah pusat sehingga dapat menggali potensi sumber pendapatan asli daerah.

2. Diharapkan pemerintah daerah kabupaten / kota Propinsi Papua yang memiliki ukuran yang lebih besar untuk dapat mengoptimalkan sumber daya yang dimiliki sehingga dapat meningkatkan kinerja keuangan pemerintah daerah tersebut. Pemerintah daerah yang memiliki ukuran daerah yang besar harus mampu menciptakan sumber daya yang mampu meningkatkan pendapatan daerah dengan menggali sumber - sumber yang baru demi peningkatan kesejahteraan masyarakat pemerintah daerah / kota Propinsi Papua, Pemerintah daerah harus dapat menciptakan sarana dan prasarana demi pembangunan dapat berjalan lancar sehingga tidak terjadi ketimpangan.

3. diharapkan dalam membiayai penyelenggaraan pemerintah daerah dengan menggunakan sumber pendanaan yang berasal dari internal tanpa harus melakukan sumber pendanaan dari pihak eksternal. Sehingga kinerja keuangan yang dimiliki pemerintah daerah kabupaten / kota Propinsi Papua akan lebih baik.

4. Diharapkan pemerintah daerah dapat menyalurkan dana transfer yang diberikan pemerintah pusat untuk penyelenggaraan pembangunan di kabupaten / kota Propinsi Papua sehingga pembangunan dapat berjalan dengan merata di tiap daerah kabupaten / kota Propinsi Papua, perlunya perbaikan infrastruktur daerah kabupaten / kota Propinsi Papua sehingga dapat tercipta pembangunan di segala bidang sehingga berdampak pada kegiatan ekonomi di daerah tersebut dan kinerja keuangan yang dihasilkan akan semakin baik.

\section{Daftar Pustaka}

Abdullah,2004. Perilaku Opportunistik legislatif dalam Penganggaraan Daerah Pendekatan Principal - Agent Theory.Makalah disajikan pada seminar antar bangsa di Universitas Bengkulu.

Abdul, Halim, 2002. Akuntansi Sektor Publik dan Akuntansi Keuangan Daerah.Edisi Pertama, Salemba Empat, Jakarta.

Adi,2006.HubunganAntara Pertumbuhan Ekonomi, Belanja Pembangunan Dan Pendapatan Asli Daerah. Procedding Simposium Nasional Akuntansi IX, Padang.

Arikunto, 2002.Prosedur Penelitian Suatu Pendekatan Praktek. Jakarta, Rineka Cipta.

Azhar,2008. Analisa Kinerja Keuangan Pemerintah Daerah Kabupaten / Kota sebelum dan setelah otonomi Daerah.Universitas Sumatera Utara.

Baber, 2010.An Empirical Investigation of Accounting Restatement and Governance in the Municipal Context.Working Paper Series.SSRN August.

Bastian, 2006.Sistem Akuntansi Sektor Publik.Edisi Pertama. Andi.Yogyakarta. 
Bhinadi,2003. Disparitas Pertumbuhan Ekonomi Jawa Dengan Luar Pulau Jawa. Jurnal Ekonomi Pembangunan Vol.8 No.1: 39-48.

Choiriyah,2010. Informasi Perbedaan Pengungkapan di Indonesia. Skripsi Universitas Sebelas Maret.

Cohen and Kaimenakis,2008. An Empirical Investigation of Greek Municipalities "Quality Of Financial Reporting. Working Paper series.

Cooke,1992. The Impact of size, Stock Market Listing and Industry Type On Disclosure In The Annual Reports Of Japanese Listed Companies. Accounting And Business Research, Vol.119: 113 - 124.

Chow,1998. The Balanced Scorecard : A Potent Tool For Energizing And Focusing Health. Care Organisation Management. Journal Of Health - Care Management.

Dian Batubara,2010. Penilaian Efektivitas Injeksi Platelet Rich Plasma Perineural Terhadap Sensibilitas Neuropati.Universitas Hasanudin.

Elmi,2002. Keuangan Pemerintah Daerah Otonom Di Indonesia. Jakarta : UI.

Fred Weston Dan Thomas Copeland, 1997. Manajemen keuangan.Edisi Kesembilan.Jilid II,Binarupa Aksara,Jakarta.

Greiling.2005. Performance Measurement In The Public Sector: The German Experience. Emerald Research, Vol.54: 551 - 567.

Hadi,2009. Analisa Pengaruh Pertumbuhan Ekonomi, Pendapatan Asli Daerah, Dana Alokasi Umum, Dan Dana Alokasi Khusus terhadap Pengalokasian Belanja Modal.Penelitian keuangan Akuntansi Sektor Publik II Badan Litbang Departemen Dalam Negeri, Bidakari.

Halim,2009. Akuntansi Sektor Publik dan Akuntansi Keuangan Daerah.Edisi 3, Salemba 4, Jakarta.

Hamzah,2009. Pengaruh Belanja dan Pendapatan Terhadap Pertumbuhan Ekonomi, Kemiskinan, Dan Pengangguran. Konferensi Penelitian,Jatim.

Hannifa,Cooke, 2005. " The Impact Of Culture And Governance On Corporate Social Reporting.” Journal Of Accounting And Public Policy,pp.391 - 430.

Hasibuan,2009. Organisasi Dan Motivasi Dasar Peningkatan Produktivitas.Penerbit Bumi Aksara. Jakarta

Inrarti, dan Virgasari,2011. Hubungan Antara Opini Auditor Pada Laporan Keuangan Daerah,pendapatan Asli Daerah,Dan Dana Alokasi Umum Dengan Kinerja Keuangan Daerah.Universitas Brawijaya,Malang.

Indra Bastian dan Gatot Soepriyanto, 2002. Sistem Akuntansi Sektor Publik. Buku Satu dan Dua,Salemba Empat, Jakarta.

Jugiyanto,2004. A Mechanism and Determinants Of An Agency- Cost Explanation For Dividend Payment. International Journal Of Business Vol.5 No.2.

Juliawati,et al,2012. Pendapatan Asli Daerah ( PAD ) dan Dana Perimbangan Terhadap Kinerja Keuangan Pemerintah Daerah.

Jogiyanto,2004. Metodologi Penelitian Bisnis : Salah Kaprah dan PengalamanPengalaman.Universitas Gajah Mada, Yogyakarta.

Kelly,2010. Intergovernmental Revenue Allocation Theory And Practise : An Application To Nepal.Asian Journal Of Public Administration Vol.21.No.1: 86 -113.

Kusumawardhani,2012. Pengaruh Leverage, Ukuran Legislatif, Intergovernmental Revenue dan pendapatan Pajak Daerah Terhadap Kinerja Keuangan.Skripsi Universitas Negeri,Semarang.

Mahmudi,2007. Manajemen Kinerja Sektor Publik.Edisi I,Yogyakarta.

Mangkusubroto, Guritno,1997. Ekonomi Publik. Yogyakarta : BPFE.

Mandell.1997. Performance Measurements and Management Tools In North Carolina Local Government.Public Administration Quarterly.Spring.Vol 21 : 96.

Mardiasmo, 2002. Otonomi Dan Manajemen Keuangan Daerah.Edisi Pertama. Andi.Yogyakarta.

Martono,2011. Penelitian Kuantitatif (Analisis Isi Dan Analisis Data Sekunder). Rajawali Pers Jakarta. 
Mustikarini Dan Fitriasari, 2012. Pengaruh Karakteristik Pemerintah Daerah dan Temuan Audit BPK Terhadap Kinerja Pemerintah Daerah Kabupaten / Kota Di Indonesia Tahun Anggaran 2007.Simposium Nasional Akuntansi XV : Banjarmasin.

Nam,2001.Looking For Appropriate Forms Of Intergovernmental Transfer For Municipalities In Trasition Economics.CES If Working Paper.

Pattrick 2007.The Detterminant Of Organizational Inovatines : The Adoption Of GASB 34 In Pennsylvania local Government.Unpublished Ph.D Dissertation.Pennsylvania : The Pennsylvania State University.

Peraturan Pemerintah No.24 Tahun 2005 Tentang Standar Akuntansi Pemerintahan.Jakarta.

Perwitasari,2010. The Influence Of Financial Performance To The Level Of Accountability Disclosure Of Indonesia's Local Government.Tesis Universitas Sebelas Maret, Surakarta.

Ramasamy,Ong,Yeung,2005. Form Size Ownership And Performance In The Malaysian Palm Oil Industry.Asian Academy Of Management Journal Of Accounting And Finance.Vol.1 : 81 - 104.

Rustiadi,2010.Perencanaan Dan pengembangan Wilayah.Jakarta : Crestpent Press dan YOI.

Samsulbar Saleh,2003. Kemampuan Pinjam Daerah Kabupaten Dan Kota Di Indonesia.Vol.XIV No.2 Desember 2003.Media Ekonomo Dan Bisnis ,Semarang.

Saragih,2003.Desentralisasi Fiskal Dan Keuangan Daerah Dalam Otonomi Daerah.Penerbit Ghalia Indonesia,Jakarta.

Sartono,2010.Analisa Pengaruh Profitabilitas,Pertumbuhan Asset,Dan Ukuran Perusahaan Terhadap Struktur Modal.Skripsi Universitas Diponegoro,Semarang.

Simanjuntak,2005.Manajemen Dan Evaluasi Kerja. Lembaga Penerbit FEUI,Jakarta.

Subanda,2007.Dasar - Dasar Penelitian Ilmiah. Bandung : CV. Pustaka Setia.

Sudarmadji dan Lana Sularto,2007. Pengaruh Ukuran Perusahaan, Profitabilitas, Leverage, dan

Tipe Kepemilikan Perusahaan Terhadap Luas Voluntary Disclosure Laporan

Keuangan Tahunan.Procedding Psychology, Economy, Art, Architect And Civil.

Gunadarma University.

Sugiyono,2007. Statistik Untuk Penelitian.Jakarta,Alfabeta.

Suhardjanto,2010.Mandatory Disclosure Compliance And Local Government Charakteristics :

Evidence From Indonesian Municipalities. Journal Public policy.

Susanto,2010.Evaluasi Kinerja Keuangan Daerah Pemerintah Propinsi Nusa Tenggara Barat

Tahun Anggaran 2003 - 2007.Journal Ganec Swara Edisi Khusus Vol. 4 No.3 ,Universitas Mataram.

Undang - Undang No.22 Tahun 1999 Pasal 79 Tentang Sumber Pendapatan Daerah.

Undang - Undang RI No.33 Tahun 2004 Tentang Perimbangan Keuangan Antara Pusat Dan Daerah.

Undang - Undang No.17 Tahun 2003. Tentang Pajak Penghasilan.

Undang - Undang No.3 Tahun 2004.Perubahan Atas Undang - Undang RI Nomor 23 Tahun 1999 Tentang Bank Indonesia.

Westin,1998. Performance Measurement And Evaluation Definition And RelationShip.GAO Issued.

Wibowo,1995.Evaluasi Kebijakan Publik.Jakarta: Rajawali Press.

Widjaja,2002.Titik Berat Otonomi Pada Daerah Tingkat II. Jakarta. Rajawali Press.

Whittaker,1995.Government Performance And Result Act, A Mandate For Starategic Planning And Performance Measurement.

Wood,1998.Local Government Dollars \& Sense ( Rancho Palos Verdes,CA : Training Shoppe ) .

Yuwono,2005. Psikologi Industri Dan Organisasi.Fakultas Psikologi, Universitas Erlangga. 